\title{
FLUCTUATING ASYMMETRY REFLECT THE GROWTH OF HYBRID GROUPER Epinephelus fuscoguttatus AND Epinephelus polyphekadion
}

\author{
Ketut Sugama")\#, Ahmad Muzaki"*), I Gusti Ngurah Permana ${ }^{* *}$, and Haryanti**) \\ ") Center for Aquaculture Research and Development, Jakarta \\ **) Research and Development Institute for Mariculture, Gondol, Bali
}

(Received 26 September 2014; Final revised 4 November 2014; Accepted 10 November 2014)

\begin{abstract}
S
Fluctuating asymmetry has been widely used as a measure of developmental stability and as an indicator of individual fish growth. The present study compared fluctuating asymmetry in three bilateral meristic traits of $\mathrm{F}-1$ hybrid between female Epinephelus fuscoguttatus and male Epinephelus polyphekadion and two F-1 pure parental progenies. The fishes were reared by communal and separate tank systems. Hybrids were confirmed by allozymes electrophoresis. After three months of rearing, the F-1 hybrids fish grew faster $45.9 \%$ and $66.6 \%$ compare to the F- 1 pure parental progenies of E. fuscoguttatus and E. polyphekadion $(\mathrm{P}<005)$ respectively. Development stability as measured by fluctuating asymmetry was lower in hybrid (20\%-40\%) than in the pure parental progenies (53\%-80\%). Among four enzyme loci examined, only Pgm locus showed variants and at that locus all hybrids fish were heterozygous. Heterozygous hybrids showed lower fluctuating asymmetry and related to higher developmental stability. The higher developmental stability positively reflected a faster growth rate. Thus this finding can be used to explain the reason that why hybrids groupers appeared grew faster than parental species.
\end{abstract}

KEYWORDS: assymmetry, hybrid, grouper

\section{INTRODUCTION}

The differential development of a bilateral character between sides of an organism is known as asymmetry (Tomkins \& Kotiaho, 2011). Fluctuating asymmetry is aparticular form of biological asymmetry characterized by small random deviations from perfect asymmetry. Fluctuating asymmetry results when a characters present on both sides of the body does not undergo identical development. It is also known that fluctuating asymmetry represent the degree of developmental sensitivity to environmental and genetic stress (Jawad et al., 2010).

Asymmetry of an individual fish is measured as the right minus the left value of the bilaterally paired traits (Leary et al., 1985; Tomkins \& Katiaho, 2001). Fluctuating asymmetry is the difference between counts of left and right bilateral meristic characters, such as fins, gill rackers and scales (Wagner, 1996).

Interest in fluctuating asymmetry originated because of its potential for measuring population stress and much interest has also

\# Corresponding author. Center for Aquaculture Research and Development Jl. Ragunan 20, Pasar Minggu, Jakarta Selatan 12540, Indonesia. Phone: +62 217805052 E-mail: ketut_sugama@yahoo.com 
been devoted to the examination of fluctuating asymmetry as an indicator for individual quality of fish. Recently, interests in studies of fluctuating asymmetry have been used as an indicator of genetic stress (Ayoade et al., 2004; Al Mamry et al., 2011 ).

Two major genomic features that have been thought to benefit developmental stability of individuals are heterozygosity and genomic coadaptation. There are also other factors, more or less related to the above two, that have been suggested to have an effect on the development stability of individuals and thus level of fluctuating asymmetry (Lu \& Bernatchez, 1999).

These factors include (1) loss of genetic variance due to inbreeding, (2) heterozygosity of protein polymorphism, suggested to be positively related to growth rate and developmental stability, and (3) hybridization should increase developmental stability and thus be reflected as reduces level of flutuating asymmetry (Tomkins \& Katiaho, 2001).

Published paper investigated the growth performance of two species of groupers (Epinephelus fuscoguttatus and Epinephelus polyphekadion) and their hybrid have shown that F-1 hybrid grew faster than F-1 pure parental progenies (James et al., 1999). There is no clear explanation why hybrid fish grew faster compared to both parental progenies.

To date, no published study on fluctuating asymmetry in grouper hybrid species. According to Leary et al. (1984) homozygous individual often shows more fluctuating asymmetry than heterozygous and this has lead to theoritical expectation that increase heterozygotes should decrease fluctuating asymmetry hence increase developmental stability. By using allozyme analyses, the F-1 hybrid should expressed both parental allele or heterozygous at a locus where both parents having different banding pattern of allele at certain locus (Sugama et al., 1988).

The present study compared fluctuating asymmetry in three meristic traits of hybrids between female Epinephelus fuscoguttatus and Epinephelus polyphekadion and their F-1 pure progenies derived from both parents to test the hypothesis that heterozygosity of enzymatic loci is related to fluctuating asymmetry of hybrid fish. Fluctuating asymmetry would belower than pure parental progenies, hence positively related to developmental stability and growth rate.

\section{MATERIALS AND METHODS}

The broodstock of Epinephelus fuscoguttatus and Epinephelus polyphekadion were used to produce pure $\mathrm{F}-1$ progenies and their F-1 Hybrid. For cross breeding, the female of $E$. fuscoguttatus and male E. polyphekadion were kept separately and after confirmation of the gonadal maturation of female $E$. fuscoguttatus, then male E. polyphekadion was introduced in female tank. These fish was used to produce two pure parental progenies of crossed between female $E$. fuscoguttatus $x$ male $E$. fuscoguttatus $\left(\mathrm{F}_{\mathrm{f}} \times \mathrm{F}_{\mathrm{m}}\right)$ and crossed between female $E$. polyphekadion and male $E$. polyphekadion $\left(\mathrm{P}_{\mathrm{f}} \times \mathrm{P}_{\mathrm{m}}\right)$ and one hybrid crossed between female $E$. fuscoguttatus and male $E$. polyphekadion $\left(\mathrm{F}_{\mathrm{f}} \times \mathrm{P}_{\mathrm{m}}\right)$. Detail procedures on production of pure progenies and hybrids, larval rearing up to 40 days after hatching where all larval have already mertamorphosed followed Sugama et al. (2012) and Zaki (2014) (personal communication).

A fifty each of pure progenies of $E$. fuscoguttatus, E. polyphekadion and hybrid juveniles were selected and stocked in one circular tank at capacity of $3 \mathrm{~m}^{3}$ for further rearing. Juveniles were communal cultured in order to avoid an environmental influence on growth, followed the formula of $V_{p}=V_{g}+V_{e}$, Where $V_{p}$ is penotypic variance, $V_{g}$ is genotypic variance, and $\mathrm{V}_{\mathrm{e}}$ is environment variance. In this study $\mathrm{V}_{\mathrm{e}}=0$, therefore $\mathrm{V}_{\mathrm{p}}=\mathrm{V}_{\mathrm{g}}$. Other fifty each of three types of juveniles was stocked in different three tanks at capacity of $1 \mathrm{~m}^{3}$ as control for growth.

Chopped trash fish composed mainly of sardinella and anchovy added with $1 \%$ vitamin mix was used for feed. The fishes were fed twice a day at satiation on each feeding time in the morning $(8-9 \mathrm{am})$ and in the afternoon (4-5 pm). All fishes were sampled after three months of rearing period (equal to 130 days after hatching). Total length and body weight were measured and some juveniles were randomly selected for further used on biochemical genetic allozymes and fluctuating asymmetry of bilateral meristic counts.

\section{Biochemical Genetics}

Biochemical genetics of allozyme electrophoresis was used to confirm hybrid fish. The 
terms of allozymes refer to products of different allelic forms of enzyme coding gene. The advantages of allozymes are their codominant nature and relatively low cost. Allozyme data were used for detecting hybridization and genetic heterozygosity of hybrid followed Sugama et al. (1992) and Swofford et al. (1996).

Electrophoresis methods used were including preparations of organ tissue sample, gel, buffer, and staining techniques followed Sugama et al. (1988). Based on previous study on allozyme electrophoresis of grouper, it was revealed that best tissue sample for analysis is liver, $10 \%$ starch gel with Citric Acid Aminopholymorpholine (CAPM) buffer at $\mathrm{pH} 7.0$ and enzymes showing clearest banding patterns are Isocitrate dehydrogenase (IDH-1.1.1.42), Malate Dehydrogenase (MDH-1.1.1.37), Glucose Phosphate Isomerase (GPI-5.3.1.9) Phosphoglucomutase (PGM-2.7.5.1) (Permana et al., 2001). Thirty of fish samples were analysed for each group.

\section{Fluctuating Asymmetry}

Fifteen fishes of each group were analysed. Fluctuating asymmetry was assesed by counting in three bilateral meristic characters (gill racker counts, pectoral fin rays and pelvic fin rays counts). All of the characters were counted under a binocular microscope projector.

Asymmetry was calculated as the value of right side ( $R$ ) and minus left ( $L$ ) side measurement $(R-L)$, whereas fluctuating asymmetry correspond to their absolute values of (|R LI). Statistical analyses included calculating the squared coeficient of asymmetry variation $\left(\mathrm{CV}^{2}{ }_{\mathrm{a}}\right)$ for meristic characters followed Valentine (1993):

$$
\mathrm{CV}_{\mathrm{a}}{ }_{\mathrm{a}}=\left(\mathrm{SD} \times 100 / \mathrm{X}_{\mathrm{R}+\mathrm{L}}\right)
$$

where:

$\mathrm{SD}$ is the standard deviation of signed differences and $X_{R+L}$ is the mean of the characters, which calculated by adding the absolute scores for right (R) and left (L) sides and dividing this by the sample size.

\section{RESULTS}

After three months of rearing, the size of fishes were presented in Figure 1 and Table 1. The size of hybrid fish $\left(F_{f} \times P_{m}\right)$ was much bigger and significantly diffrerent $(P<0.05)$ to both pure parental progenies $\left(F_{f} \times F_{m}\right.$ and $\left.P_{f} \times P_{m}\right)$, while $F_{f} \times F_{m}$ growth was faster than $P_{f} \times P_{m}$

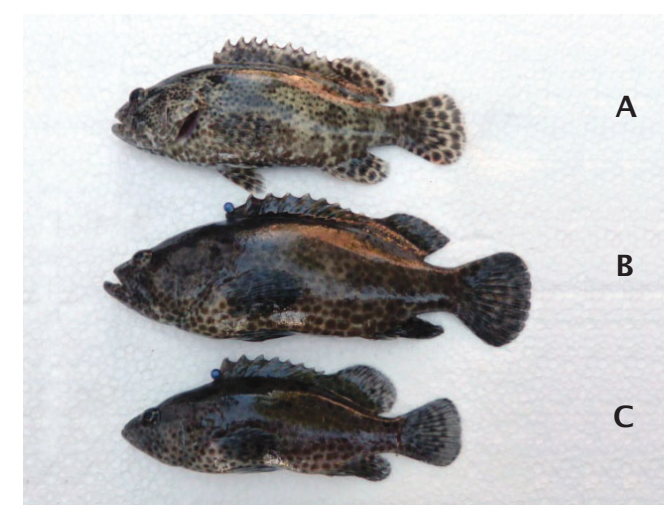

Figure 1. Phenotypes of Epinephelus fuscoguttatus (A), hybrids (B), and $E$. polyphekadion (C)

progenies $(P<0.05)$. Growth rates of pure progenies and hybrid cultured at different tanks were also showing similar phenomenon where hybrid grew faster than both of pure parental progenies.

Among four enzymes analyzed, the only Pophglucomutase (Pgm) locus, showed the different alleles banding pattern of the two parentals fish, and hybrids fish expressed both of their parental gene, hence all hybrids were heterozygous at Pgm locus. Based on the electrophoretic banding pattern of hybrid, it was confirmed that F-1 was true hybrid and no dominant and recessive alleles between parentals. (Figure 2).

The results of asymmetry data analysis from three types of progenies were presented in Table 2. The highest value was recorded for the pectoral fin rays of E. polyphekadion (80\%) and the lowest value was for the pelvic fin rays on hybrid (20\%). Variable levels of asymmetry was observed depending on characters. In general, lower fluctuating asymmetry was observed in three charaters (gill raker, pectoral fin rays, and pelvic fin rays) in hybrid fish (Table 2).

The coefficient of asymmetry $\left(\mathrm{CV}_{\mathrm{a}}{ }_{\mathrm{a}}\right)$ is related to the fish growth (Al-Mamry et al., 2011). The fluctuating asymmetry does reflect development stability, and developmental stability was positively related to growth rate (Table 2 ).

\section{DISCUSSION}

Previous studies on fluctuating asymmetry in fishes and other organisms revealed that 
Table 1. The size (TL and BW) of three types of progenies after three months of rearing in communal and separate culture systems

\begin{tabular}{|c|c|c|c|c|c|}
\hline \multirow{2}{*}{$\begin{array}{l}\text { Type of } \\
\text { progenies }\end{array}$} & \multirow{2}{*}{$\begin{array}{l}\text { Number of } \\
\text { sample } \\
\text { (ind.) }\end{array}$} & \multicolumn{2}{|c|}{$\begin{array}{l}\text { Total body length (TL) } \\
(\mathrm{cm})\end{array}$} & \multicolumn{2}{|c|}{$\begin{array}{l}\text { Body weight (BW) } \\
(\mathrm{g})\end{array}$} \\
\hline & & $\begin{array}{l}\text { Initial } \\
\text { length }\end{array}$ & $\begin{array}{l}\text { Three months } \\
\text { of age }\end{array}$ & $\begin{array}{l}\text { Initial } \\
\text { weight }\end{array}$ & $\begin{array}{l}\text { Three months } \\
\text { of age }\end{array}$ \\
\hline \multicolumn{6}{|c|}{ Communal cult ure } \\
\hline$F_{f} \times F_{m}$ & 15 & $4.9 \pm 0.2$ & $11.79 \pm 0.91^{\mathrm{a}}$ & $2.2 \pm 0.2$ & $31.05 \pm 7.85^{a}$ \\
\hline$P_{f} \times P_{m}$ & 15 & $4.9 \pm 0.2$ & $10.46 \pm 1.28^{\mathrm{b}}$ & $2.2 \pm 0.2$ & $19.16 \pm 4.14^{b}$ \\
\hline Hybrids $\left(F_{f} \times P_{m}\right)$ & 15 & $5.0 \pm 0.1$ & $14.11 \pm 1.15^{c}$ & $2.2 \pm 0.2$ & $57.49 \pm 13.68^{c}$ \\
\hline \multicolumn{6}{|l|}{ Separate cult ure } \\
\hline$F_{f} \times F_{m}$ & 15 & $4.8 \pm 0.2$ & $11.69 \pm 1.91^{\mathrm{a}}$ & $2.1 \pm 0.2$ & $32.05 \pm 6.77^{a}$ \\
\hline$P_{f} \times P_{m}$ & 15 & $5.0 \pm 0.3$ & $10.35 \pm 1.44^{b}$ & $2.1 \pm 0.4$ & $19.21 \pm 4.18^{b}$ \\
\hline Hybrids $\left(F_{f} \times P_{m}\right)$ & 15 & $4.9 \pm 0.2$ & $14.25 \pm 1.18^{c}$ & $2.1 \pm 0.3$ & $57.41 \pm 12.77^{c}$ \\
\hline
\end{tabular}

Different superscript letters are significantly different $(P<0.05)$

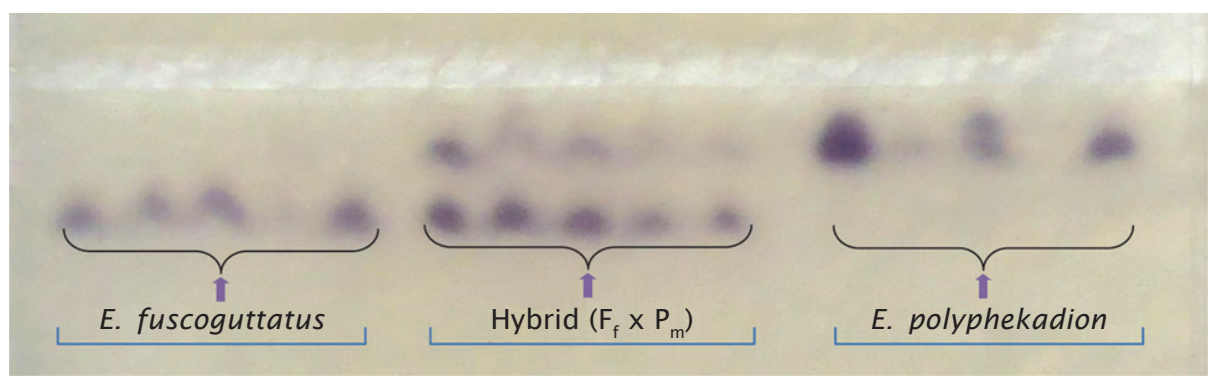

Figure 2. Electrophoretic banding pattern of Epinephelus fuscoguttatus, hybrid, and E. polyphekadion

decreased of fluctuating asymmetry in F-1 hybrid progeny compared to pure F-1 parental progenies (Palmer \& Strobeck, 1986; Leary \& Allendorf, 1989). As mentioned by Leary et al. (1984) that fluctuating asymmetry does reflect developmental stability, as in the present result suggest that hybrids were more fit and grew faster than pure progeny of $E$. fuscoguttatus and E. polyphekadion (Table 2).

Developmental stability as measured by fluctuating asymmetry was lower in hybrids than in the pure parental progenies as shown in the present study (Table 2). Fluctuating asymmetry significantly lower in meristic characters (number of gill raker, pectoral fin rays, and pelvic fin rays) in hybrids (Table 2 ).

Present study revealed that all hybrids individuals were heterozygous in Pgm locus as shown in Figure 2. Heterozigosity of protein or enzyme polymorphism is an indicator of genetic variability and has been sugested to be positively related to several fitness components such as viability, growth rate, and developmental stability (Sugama et al., 1992; Tomskin \& Kotiaho, 2001). The heterozygosity of Pgm locus is related to the degree of fluctuating asymmetry in three characters of hybrids and pure parental progenies. The hybrid fish showed lower fluctuating asymmetry than pure parental progenies. This phenomenon is common and the possibility that the correlation is due to the direct effect of a particular locus (Leary et al., 1984)

Individual heterozygous in certain locus may have higher fitness because they also showed a relatively high level of individual 
Table 2. Characteristic of square coefficient of asymmetry $\left(\mathrm{CV}_{\mathrm{a}}{ }_{\mathrm{a}}\right)$ and character mean $\left(\mathrm{X}_{\mathrm{R}+\mathrm{L}}\right)$ of F-1 progenies for $E$. fuscoguttatus, E. polyphekadion, and their F-1 hybrids

\begin{tabular}{lcccc}
\hline $\begin{array}{c}\text { Progenies/ } \\
\text { Characters }\end{array}$ & $\begin{array}{c}\text { Number of } \\
\text { samples }\end{array}$ & $\mathbf{C V}^{2}{ }_{\mathbf{a}}$ & Mean & $\begin{array}{c}\text { Percentage of indivi- } \\
\text { duals with asymmet ry }\end{array}$ \\
\hline $\begin{array}{l}\text { E. fuscogut tat us } \\
\text { Gill raker }\end{array}$ & 15 & 20.44 & 37.13 & 66.7 \\
Pectoral fin ray & 15 & 9.80 & 32.20 & 66.7 \\
Pelvic fin rays & 15 & 16.13 & 30.40 & 60.0 \\
\hline E polyphekadion & & & & \\
Gill raker & 15 & 25.37 & 37.50 & 60.0 \\
Pectoral fin ray & 15 & 9.88 & 37.19 & 80.0 \\
Pelvic fin rays & 15 & 11.33 & 29.68 & 53.3 \\
\hline Hybrids & & & & 40.0 \\
Gill raker & 15 & 11.33 & 40.13 & 26.7 \\
Pectoral fin ray & 15 & 2.88 & 39.33 & 20.0 \\
Pelvic fin ray & 15 & 6.88 & 31.27 & \\
\hline
\end{tabular}

homeostasis or stability (Britten, 1996). In fact, at present study heterozygous individual at $\mathrm{Pgm}$ locus in hybrids resulted in lower fluctuating asymmetry and related to greater developmental stability and positively related to faster growth rate (Table 2 ).

Similar studies have shown that F-1 hybrid grew faster than their pure F-1 parentals progenies (James et al., 1999; Ismi et al., 2013). BPBAP Situbondo (2012) have published data on hybrid between female $E$. fuscoguttatus and male E. lanceolatus and shows that $\mathrm{F}-1$ hybrids grew faster than pure progenies of both parental. Those finding could be explained by the fact that heterozygosity of certain enzymatic loci is related to lower fluctuating asymmetry and greater developmental stability which is positively related to growth rate (Leary et al., 1984).

Heterozygous are predicted to show lower level of fluctuating asymmetry than homozygous. If the level of fluctuating asymmetry is determined by one locus or a few loci, then differences in fluctuating asymmetry should be more readily detected between individuals hybrids than between individuals from pure progenies.

Field observation of hybrid and pure parental progenies of grouper cultured in communal system, indicated that hybrid grouper is more active in seeking food, and always lead- ing in competition to find food compare to pure progenies. Assuming that fluctuating asymmetry does reflect developmental stability meaning that hybrids were more fit than pure progeny parental grouper.

\section{CONCLUSIONS}

The present study approved that heterozygosity of enzymatic loci is related to development stability as measured by fluctuating asymmetry. Fluctuating asymmetry of hybrid fish was lower than pure parental progenies, hence increase developmental stability in which positively related to growth rate. This finding could explain that hybrids groupers generally grew faster than parental species.

\section{REFERENCES}

Al-Mamry, J., Jawad, L., Al-Bimami, S., Al-Gafari, F., Al-Mamry, D., \& Al-Marzouki, M. (2011). Asymmetry in some morphological characters of Leognatus equalus (Forskal) Leognathidae Collected from the sea of Oman. Arch. Pol. Fish., 19, 51-55.

Ayoade, A.A, Sowunmi, A.A., \& Nwachukwu, H.I. (2004). Gill asymmetry in Labeo ogunensis from Ogun river, Southwest Nigeria. Rev. Biol. Trop., 52(1), 171-175.

BPBAP Situbondo. (2012). Hybrid between female tiger grouper, Epinephelus fuscoguttatus and male Epinephelus lanceolatus, 
Kertang. Ditjen Perikanan Budidaya, $2 \mathrm{pp}$.

Britten, H.B. (1996). Meta analyses of the association between multilocus heterozygotes and fitness. Evolution, 56, 2158-2164.

Ismi, S., Asih, Y.N., \& Kusumawati, D. (2013). Peningkatan produksi dan kualitas benih ikan kerapu melalui Hibridisasi. J. IImu dan Teknologi Kelautan Tropis, 5(2), 333-341.

James, C.M., Al-Thobalti, S.A., Rasem, B.M., \& Carlos, M.H. (1999). Potential of grouper hybrids (Epinephelus fuscoguttatus $\times E$. polyphekadion) for Aquaculture. Naga, The ICLARM Quaterly, 22(1), 19-23.

Jawad, L.A, Al-Mamry, J.M., Akharusa, A.A., \& AlHabsi, S.H. (2010). Asymmetry in certain morphological characters of the carangid species Decapterus ruselli, collected from Lemah coastal areas, on the Northern part of Oman Sea Ocean. Hydrob. Studies, 39, 55-62.

Leary, R.F., Allendorf, F.W., \& Knudsen, L.K. (1984). Superior development stability of heterozygous at enzyme loci in salmonid fishes. Am. Nat., 124, 540-551.

Leary, R.F., Allendorf, F.W., \& Knudsen, L.K. (1985). Development instability and high meristic counts in interspecific hybrid of salmonnids fishes. Evolution, 39, 1318 1326.

Leary, R.F., \& Allendorf, F.W. (1989). Fluctuating asymmetry as an indicator of stress in conservation biology. Trend. Ecol. Evol., 4, 214-217.

Lu, G., \& Bernatchez, L. (1999). A study of fluctuating asymmetry in hybrids of dwarf and normal lake white fish ecotypes (Coregonus clupeaformis) from different glacial races. Heredity, 93, 742-747.
Palmer, A.R., \& Strobeck, C. (1986). Fluctuating asymmetry measurement analyses, patterns. Ann. Rev. Ecol. Sust., 17, 391-421.

Permana, I G.N, Sembiring, S.B.M., Haryanti, \& Sugama, K. (2001). Pengaruh domestikasi terhadap variasi genetik pada kerapu bebek (Cromileptes altivelis). J. Pen. Perik. Indonesia, 7(1), 25-30.

Sugama, K., Taniguchi, N., \& Umeda, S. (1988). Isozyme expression of artificially induced ploidy in red sea bream (Pagrus major), black sea bream (Acanthophagus schlegeli) and their hybrid. USA Mar. Biol. Sci., 10, 2229.

Sugama, K., Taniguchi, N., \& Seki, S. (1992). Survival growth and gonad development of triploid red sea bream, Pagrus major. Use of isozyme marker for ploidy and family identification. Bull. Aquac. Fish. Manag. Europe, 45, 112-119.

Sugama, K., Rimmer, M.A., Ismi, S., Koesharyani, I., Suwirya, K., Giri, N.A., \& Alava, V.R. (2012). Hatchery management of groupers. Australian Center for International Agriculture Research (ACIAR). Monograph Series No. 149, 66 pp.

Tomkins, J.L., \& Kotiaho, J.S. (2001). Fluctuating asymmetry. Encyclopedia of Life Science. Macmillan Publisher Ltd. Nature Publishing Group, p. 1-5.

Valentine, D.W., Soule, M.E., \& Samollow, P. (1993). Asymmetry fishes. A possible stastical indicator of environment. Fish. Bull., 71, 357-370.

Wagner, E.J. (1986). History and fluctuating asymmetry of Utah salmonid broodstocks. Progressive Fish Culturist, 58, 92-103. 